\title{
Developing intercultural communicative competence - the two sides of the coin
}

\author{
Svetlana Dimitrova-Gyuzeleva \\ New Bulgarian University, Bulgaria; sgjuzeleva@nbu.bg
}

\begin{abstract}
Effective intercultural communicative competence goes beyond a good command of the foreign language and an insight into the foreign culture. What real-life intercultural communication often calls for is an ability to present one's own cultural identity in the foreign tongue. Are our learners empowered to face this challenge and how can the foreign language teacher cater for this need? The aim of this paper, which was developed on the basis of the author's presentation at the $4^{\text {th }}$ conference of the Educational Role of Language network "From theory to practice, from practice to theory", is to outline the contemporary understanding of the essence of intercultural communicative competence underpinning the need for language teachers to devote equal attention to both the target and the local culture and language in order to prepare competent language users who can function as efficient mediators in the process of intercultural communication. In an answer to some of the deficiencies identified in educational practice, some practical ideas are also shared on how to exploit the rich affordance of language classes to enhance both the language command and the intercultural communicative competence of the learners.
\end{abstract}

Keywords: intercultural communicative competence, foreign language education

\section{Introduction}

The understanding of the "cultural dimension of language" (Bennett 1997) is not a current phenomenon: nowadays both language theoreticians and practitioners in the classroom readily agree that without cultural awareness of "the social or philosophical content of that language" (ibid., p.16) the language learner would be just a "fluent fool", and that artificial languages without the cultural context to enliven and root them to real life have little chance of survival, let alone of becoming a lingua franca (e.g. Esperanto). The interrelationship between language and culture has been the subject of many studies over recent years, and acknowledged as a fundamental component of the language learning process (Kramsch 1993/1998, Byram 1997/2009, Davcheva \& Docheva 1998, Byram, Nichols \& Stevens 2001, Murray \& Thorne 2004, Byram \& Phipps 2005, Lázár et al. 2007, Candelier et al. 2007, Huber 2012, Beacco et al. 2016, etc.). This cultural turn in language teaching has been reflected in the Common European Framework of Reference: Learning, Teaching, Assessment (CEFR), the key document of the Council of Europe as far as language education is concerned, emphasizing the role of modern language education in promoting "mutual understanding and tolerance, respect for identities and cultural diversity through more effective international communication", as well as in meeting "the needs of a multilingual and multicultural Europe by appreciably developing the ability of Europeans to communicate with each other across linguistic and cultural boundaries" (ibid. 2001: 3). Thus the plurilinguistic and intercultural communicative competences are seen as the essential features of the European democratic citizenship, built on a strong sense of European identity and understanding of the values and foundations on which the European peoples intend to base their development today - i.e. the principles of democracy, social justice and respect for human rights (cp. Heater 1992). The Companion Volume [to the CEFR] with New Descriptors (Council of Europe 2018) has taken a step further in updating and extending the descriptors of language communicative competence to reflect the complexity of language proficiency and multifaceted character of language use: one of the major amendments concerns the addition of special descriptor scales for plurilingual/pluricultural and mediation competences.

As a result of all those developments in the field of language education (incl. FLT textbook publishing) it could safely be argued that today more and more foreign language teachers see themselves as teachers of both language and culture. However, they are often primarily engaged in developing their students' cultural competence associated with the target language culture only, ignoring almost 
completely the students' own cultural background. So, it is still mostly up to the individual teachers to introduce elements of intercultural learning, i.e. to elaborate on the topics of textbook materials in a way that allows the students to enhance their intercultural communicative competence and personal development through reflecting on and discussing various aspects of their own culture and/or cultural assumptions in parallel and comparison with the target language culture.

The aim of this paper is on one hand to outline the contemporary understanding of the essence of intercultural communicative competence underpinning the need for language teachers to devote equal attention to both the target and the local language and culture, and on the other to share some practical ideas on how to exploit the rich affordance of language classes to enhance both the language command and the intercultural communicative competence of the learners.

\section{Theoretical background}

What is the essence of intercultural communicative competence? The understanding that effective foreign language communicative competence requires something more than just a good command of the vocabulary and grammar structure of the foreign language itself is not new to the theory of foreign language education. At the turn of the century Milton Bennett humorously referred to a person who "speaks a foreign language well but does not understand the social or philosophical content of that language" as a "fluent fool" (Bennett 1997: 16), and Claire Kramsch takes language as cultural semiotic and holds that "as long as culture acquisition means the ability to momentarily see the world through the eyes of a native speaker or to occasionally behave in ways that conform to native speaker expectations, culture acquisition should be a desirable goal of language learning" (Kramsch 1998: 33).

Noam Chomsky (1965) was the first applied linguist to differentiate between "linguistic competence" and "linguistic performance"; he described competence as the idealized mental capacity, the knowledge that a speaker or listener has of language, and performance (which he called parole) as the actual use of language in concrete communicative situations. Chomsky later introduced two more terms to elucidate the distinction between competence and performance: namely, "grammatical competence" and "pragmatic competence", restricting the former to knowledge of language form and meaning and the latter to knowledge of how to use language appropriately, in conformity with the communicative purpose (Chomsky 1980: 224). A similar emphasis on language as "a social semiotic resource" used by people "to accomplish their purposes by expressing meaning in context" (Halliday 1978: 111) is put by the representatives of functional linguistics and sociolinguists. For them the communicative context extended to include the nonverbal environment in which the communication takes place - is determined by two major factors: the communicative situation itself and the culture of the participants. Thus, they argued, different facets of the social context may have an impact on language use, such as role relationships, "power structure and patterns of social control", culturally-determined symbolic systems and systems of values (Halliday 1973: 63).

The term "communicative competence" itself was introduced by Dell Hymes (1972) to refer to the potential of a language user to communicate effectively with the other language users, i.e. the ability for effective performance in real-life communicative situations. For him the concept of communicative competence subsumed not only the grammaticality / linguistic accuracy of language use but also the contextual appropriacy and social acceptability of verbal behavior. In other words, although one can have linguistic competence and be able to produce linguistically correct utterances, $s /$ he will not be able to communicate effectively if $s$ /he lacks knowledge of the rules for language use: "There are rules of use without which the rules of grammar would be useless" (Hymes 1972: 278). It is interesting to note that in the concept of communicative competence Dell Hymes includes some non-verbal elements related to appropriate communicative conduct such as "attitudes, values, and motivations concerning language, its features and users" (ibid.) which could be used to distinguish even between native speakers of the 
language in terms communicative competence (e.g. native speakers may be equally linguistically competent but they vary in their confidence or ability to integrate humor in their speech).

In the 1980s Canale and Swain (Canale \& Swain 1980, Canale 1983) provided a more detailed description of the communicative competence along the same lines (which later was used as the theoretical foundation of the Communicative Approach to language teaching and incorporated in the Common European Framework of Reference ${ }^{1}$ ), comprising the following components:

- grammatical competence: the knowledge of the lexical items and grammar rules;

- sociolinguistic competence: the ability to communicate appropriately in a variety of contexts (incl. both verbal and non-verbal communication);

- discourse competence: the ability to use language in communication cohesively and coherently (i.e. familiarity with the structural and semantic ties that keep a text together);

- strategic competence: competent usage of communication strategies to overcome or repair communication breakdown, resulting from lack of linguistic competence or background information on cultural frameworks of communication and social taboos (cp. Canale \& Swain 1980, Canale 1983).

Thus the concept of communicative competence and the prominence given to its sociolinguistic/sociocultural dimension (i.e. the skills for effective language use in real-life communicative situations) turned into the cross-section of language and culture in language education theories. Taking into account the culturally determined character of communicative competence (which may only be realized by native speakers of the language in situations of intercultural communication - i.e. when interacting with people from another culture), Michael Byram (1997) proposes his multidimensional model of intercultural communicative competence (see Figure 1) as an extension of the communicative competence concept which includes intercultural competence.

Figure 1: Michael Byram's model of intercultural communicative competence (1997: 73).

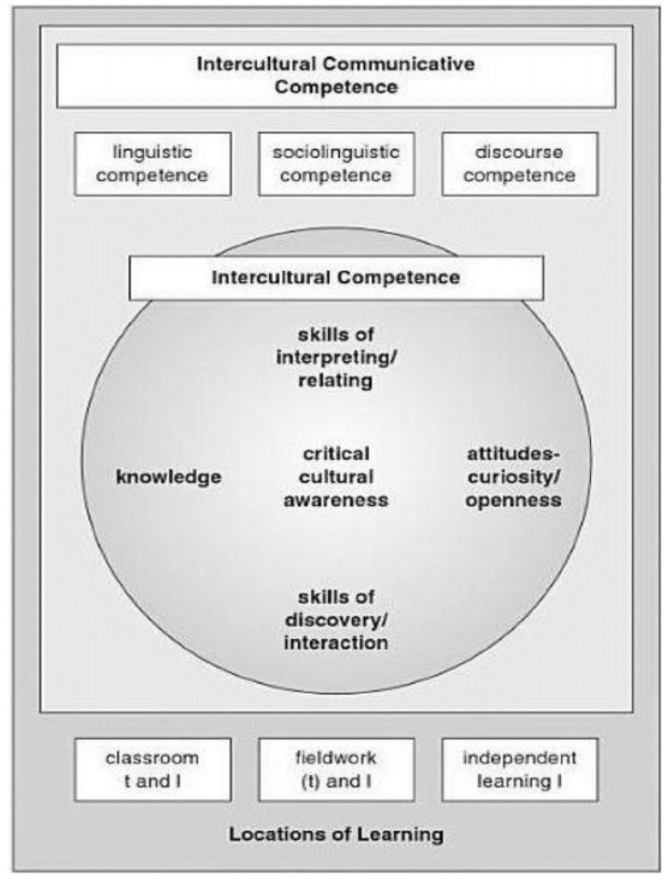

\footnotetext{
1 "Communicative competence refers to a person's ability to act in a foreign language in a linguistically, sociolinguistically and pragmatically appropriate way" (CEFR, 2001: 9).
} 
Byram's (ibid.) conceptual model of intercultural competence comprises five specific, interrelated components - culture-relevant knowledge, skills and attitudes, or savoirs, as he calls them - which, together with communicative competence itself (which in itself can be considered a sixth savoir), allow a person to adequately function in situations of intercultural communication, i.e. be an interculturally competent speaker (Byram 2009). The first of these savoirs has been defined as "knowledge about social groups and their cultures in one's own country, and similar knowledge of the interlocutor's country on the one hand, and similar knowledge of the processes and interaction at individual and societal levels, on the other hand" (Byram 1997: 35), as well as an insight regarding the ways in which culture affects language and communication. These savoirs (the term is deliberately used in the plural), according to Byram (ibid.), constitute a culture-specific frame of reference for interpreting meaning in intercultural communication: i.e. the words and gestures people use, the behaviors they display, the values they cherish, etc. are always culture-bound and "carry specific meaning within a particular cultural frame of reference". Hence, he argues, in situations of intercultural communication it is important to be sensitive to potential referential differences. Notably, Byram (ibid.) holds that along with exploring the national identity of the target culture and the home culture, the interculturally competent person also needs to acquire "a certain amount of culture-general knowledge" (ibid.) which will allow him/her to deal more successfully with the diversity of foreign cultures and accept the existence of "otherness" (i.e. different behaviors and ways of thinking, even ones s/he may not necessarily agree with). Savoir-apprendre, savoir-comprendre and savoir-faire together constitute the skills dimension of Byram's intercultural competence conceptual framework. Savoir-apprendre refers to the ability to acquire new knowledge about cultures and cultural practices, incl. making use of metacognitive strategies to self-direct one's own learning and seek out and discover aspects of culture even while interacting, under the constraints of real-life communication. Savoir-comprendre refers to the capacity to relate (compare and contrast) cultures and interpret them, assigning meaning to cultural events and phenomena in an independent, unbiased way, as well as relate those interpretations to one's own culture and experience. Savoir-faire refers to the overall critical cultural awareness of the language speaker/user and the ability to act in an "interculturally competent way" in situations of intercultural contact, i.e. to take into account the specific cultural identity of the interlocutor and to behave in a respectful and co-operative way (ibid.). Finally, the intercultural speaker's attitudes of openness and curiosity - savoir-être and savoir-s'engager - are related to the general disposition of the individual to critically engage with the foreign culture in relation to one's own, i.e. to acquire intercultural competence (savoir-s'engager), and "the capacity and willingness to abandon ethnocentric attitudes and perceptions, and the ability to establish and maintain a relationship between one's own and the foreign culture" (savoir-être) (Byram 1997: 54). Byram (ibid.) also argues that the first factor an individual must address when trying to acquire intercultural communicative competence is the right attitude: he believes that one must be ready to "suspend disbelief about other cultures and belief about one's own", to be willing to "remain open to learning about new beliefs, values, and worldviews in order to participate in relationships of equality" and respect for human dignity when communicating with people from other cultures.

Byram's model of intercultural communicative competence is used as a point of departure in a number of studies - some more theoretical in character, others with a more pragmatic focus attempting to further elucidate the essence of the conceptual construct and/or decompose its cognitive content (e.g. Candelier et al. 2007: 50-52, Companion Volume [to the CEFR] with New Descriptors, 2018: 30, 157-159), or to propose some practical approaches to developing and accessing intercultural communicative competence in the foreign language classroom (e.g. Davcheva \& Docheva 1998, Byram, Nichols \& Stevens 2001, Murray \& Thorne 2004, Byram \& Phipps 2005, Lázár et al. 2007, Huber 2012, Beacco et al. 2016, etc.). It is worth noting that in all of these publications intercultural competence goes hand in hand with plurilinguistic communicative competence and mediation skills as its indispensable pillars, as well as that there is at least an awareness that language teachers need to teach both the 
foreign and the local culture when trying to develop their students' intercultural communicative competence.

Initially, however, there seemed to be a greater focus on the target language culture and on making sure that foreign language learners acquire the whole pack of culture-specific knowledge, skills and attitudes that will allow them to communicate effectively with native speakers of the target language. Here are two examples of the traditional early definitions of intercultural communicative competence, which although implicitly suggesting that both participants in the communicative act should adopt these attitudes, do not seem to take into account the learner's own cultural background and imply that in order to be successful the learner should probably mimic the target culture and model his verbal behavior on the communication protocols of native speakers of the target language:

"Thus, developing the intercultural dimension in language teaching involves recognising that the aims are: to give learners intercultural competence as well as linguistic competence; to prepare them for interaction with people of other cultures; to enable them to understand and accept people from other cultures as individuals with other distinctive perspectives, values and behaviors; and to help them to see that such interaction is an enriching experience." (Byram, Gribkova \& Starkey 2002: 10)

or

"Intercultural communicative competence is the ability to communicate effectively and appropriately with people from other language and cultural backgrounds.

Effective intercultural communication requires:

- EMPATHY: an understanding of other people's behaviors and ways of thinking;

- RESPECT: genuine admiration and appreciation of different ways of thinking and communication;

- TOLERANCE: the ability and willingness to accept and acknowledge different behaviors and ways of thinking, the existence of opinions or behavior that one does not necessarily agree with;

- SENSITIVITY: the awareness and responsiveness to other people's behaviors and ways of thinking;

- FLEXIBILITY: willingness to adapt and open to change and different ways of thinking." (Sun 2014)

The learners would indeed be well-advised to conform to these requirements for effective intercultural communication when immersed in a target language communicative context, e.g. when they are in a country where the target language is spoken, though they need to pay heed not to sound and/or look unnatural (cp. Byram, Nichols \& Stevens 2001: 5). The problem with this one-sided interpretation of intercultural communicative competence arises when learners find themselves in situations of intercultural interaction with other non-native speakers of the language they use as lingua franca (when such awareness of the culture and communication protocols of native speakers of the target language would be of very little if any practical value) and/or in intercultural communicative situations when they have to present their own cultural identity in the target language and not display knowledge of the target culture (e.g. when working for the tourist industry in their own country, or when using the target language simply as lingua franca at international forums ${ }^{2}$ ).

Optimistically, attempts to rehabilitate the "other side of the coin" - i.e. the students' awareness of their own cultural identity and ability to present it adequately in the foreign tongue, underpinned by the skills and attitudes, empowering them to engage in a process of discovery of "otherness", reflecting on various aspects of their own culture and/or cultural assumptions in parallel and comparison with the

\footnotetext{
2 Aware of this pragmatic value of foreign language competence as one of the life skills in the 21 century guaranteeing academic and professional success and mobility in our globalized world, Norwegian educational experts and policy-makers are planning to scrap intercultural communicative competence (incl. knowledge of the culture and the literature of the people speaking the target language) from the goals underpinning their foreign language school curriculum (Høvik 2019).
} 
target language culture, keeping an open mind and remaining respectful of different behavioral patterns and ways of thinking - are becoming ever more frequent and more successful.

"... when teaching intercultural communicative competence, teachers need to teach both the local and international cultures. Teachers and native speakers of English need to be aware and respect nonnative speakers' different ways of communicating." (Yilin Sun, expresident of TESOL International Association 2014)

Another good point in case is the recently revised national foreign language school curriculum in Bulgaria which now incorporates this modern interpretation of intercultural communicative competence (as an amalgamation of culture-relevant knowledge, skills and attitudes concerning both the local and the target cultures) in the core content of the syllabi even for young learners at beginner level and all the way through to the final grades at school (foreign languages being one of the compulsory school subjects ${ }^{3}$ ). This educational reform has had a kind of knock-on effect on both textbook content and teaching practices, forcing major publishers to come up with Bulgarian adaptations of their foreign language coursebooks, including whole sections devoted to developing the intercultural communicative competence of the learners, encompassing both the target language culture and the local one, inviting students to critically reflect on their exponents and draw parallels, thus gaining deeper understanding of both cultures, fostering attitudes of tolerance and respect for "otherness", but also promoting stronger awareness of one's own cultural identity and safeguarding against blindly assimilating target language cultural patterns of behavior and/or foreign values (cp. Ivanov 2018).

The Companion Volume [to the CEFR] with New Descriptors (Council of Europe 2018: 30, 157-159) also does justice to the two sides of the same coin - i.e. that of intercultural communicative competence. The development of the new descriptors for plurilingual and pluricultural competence was underpinned by the beliefs that "languages and cultures are not kept in separated mental compartments" and that the success of intercultural communication depends on the speakers' willingness to act as intercultural mediators and their "capacity to deal with 'otherness', to identify similarities and differences, to build on known and unknown cultural features, etc., in order to enable communication and collaboration", as well as on their "readiness and capacity to expand linguistic/plurilinguistic and cultural/pluricultural awareness through an attitude of openness and curiosity", incl. towards their own cultures (ibid., pp. 157-158). The authors of this key document of the Council of Europe in the area of language education explicitly posit that the new descriptors of plurilingual and pluricultural competence are there to warrant the balance between the target language culture and the culture(s) of the learners, as well as to acknowledge the fact that such competence should not be taken for granted but rather be carefully fostered by the language educators, providing the necessary scaffolding:

"The main reason for associating descriptors in this area with CEFR levels is to provide support to curriculum developers and teachers in their efforts (a) to broaden the perspective of language education in their context and (b) to acknowledge and value the linguistic and cultural diversity of their learners. The provision of descriptors in levels is intended to facilitate the selection of relevant plurilingual/pluricultural aims, which are also realistic in relation to the language level of the user/learners concerned." (ibid., p. 158)

At beginner levels ( $A 1$ and $A 2$ ) the target language user/learner is more passive, only capable of recognizing culture-bound differences in communication (and possibly in life styles - e.g. differing ways of measuring distance, or telling the time), interpreting their meaning correctly and accepting "otherness"; gradually s/he begins to learn how to "apply basic cultural conventions associated with everyday social exchanges" and act appropriately in everyday transactions (ibid., pp. 158-159). At intermediate level (B1 and B2) the language user/learner builds up the needed intercultural competence and confidence to be more active and effectively engages in intercultural communication: s/he starts to

\footnotetext{
${ }^{3}$ https://www.mon.bg/bg/1698
} 
"respond to the most commonly used cultural cues, act according to socio-pragmatic conventions and explain or discuss features of his/her own culture", as well as recognize and repair simple culturallybased misunderstandings (ibid., pp. 158-159). At advanced levels (C1 and C2), this develops into an ability to critically reflect on and sensitively explain the cultural beliefs, values and practices of his/her own and of other communities showing awareness and respect for cultural difference, an enhanced capacity to interpret and discuss them, successfully coping with socio-linguistic and pragmatic ambiguity, expressing reactions constructively with cultural appropriateness and generally acting as an intercultural mediator in order to reach mutual understanding and collaboration (ibid., pp. 158-159).

\section{Practical perspectives}

Most publications related to intercultural communicative competence also offer practical suggestions on how to develop it, or rather, how to help and guide language learners to acquire it successfully. In his book "Teaching and Assessing Intercultural Communicative Competence" Byram (1997: 73) describes intercultural learning as a "linear process", beginning in the classroom under the direction and guidance of the teacher, through fieldwork and projects in which the learner is the main driving force only steered by the teacher, until s/he is ready to embark on his/her own journey of discovery and independent learning even beyond the classroom. When describing the intercultural classroom environment, authors recommend a type of learning which is "learner-centered, engaging, interactive, participatory and cooperative" (cp. Byram, Gribkova \& Starkey 2002). The student is often defined as "a researcher or discoverer of knowledge", very much like "an anthropologist who explores and investigates a topic both in and outside of the classroom"; foreign language teachers are no longer expected "to transmit to learners detailed information about the culture being studied", rather they assume the role of facilitators who only guide the learning process in order to actively involve learners and scaffold their intercultural experiences as they explore, discover, analyze and evaluate meaningful information in authentic materials (cp. Byram 1997, Byram \& Phipps 2005, etc.). Byram et al. (2002) also emphasize the fact that since culture itself is ever-changing and dynamic in character, foreign language teachers must create a learning environment of openness and curiosity in the classroom, thereby minimizing judgment about the "other" culture, and promote an attitude of inquiry in order to guide learners toward independent discovery of differing worldviews and self-directed acquisition of intercultural competence.

For Byram (1997) there is a logical progression in the process of intercultural learning. Initially, teachers should get their students to consider and start questioning their own preconceived ideas, beliefs and stereotypes in relation to the foreign culture before embarking on a process of discovery about the "other". This is done with the intent of fostering the "right" mindset of openness and tolerance of diversity along with developing a toolkit of skills for critical reflection and analysis, making students better equipped and more capable intercultural learners, as well as more willing "to seek out and engage with otherness in order to ultimately experience relationships of reciprocity and equality" (ibid., p. 71) when communicating with people from other cultures. Remarkably, in parallel to the analysis of otherness and the acquisition of knowledge about the target language culture, Byram (ibid.) argues that it is imperative for the foreign language educator to make time for his/her learners to explore the national identity of the home culture in relation to the target one in terms of history and present day socio-political institutions, geography, folk traditions and behavioral patterns, science, art and literature, etc. Once learners have discovered the similarities and differences between their culture and that of the target language, they must be provided with the educational affordance to develop skills in interpreting and relating (e.g. sensitivity, tolerance, respect, empathy, flexibility, adaptability, etc.) which will empower them to build effective relationships with people of diverse cultural backgrounds, speaking the target language (ibid.). When students begin to identify "ethnocentric perspectives and misunderstandings related to cross-cultural communication", they become able to understand and then explain the origins of conflict and mdiate such situations appropriately in order to avoid 
misinterpretations and facilitate the achievement of communicative intentions (ibid.). Finally, skills in discovery and interaction allow intercultural speakers to independently seek out opportunities to meet people from diverse cultures and gain new information in order to develop as individuals and establish meaningful relationships based on equality with people from other cultures (ibid.).

Unlike Byram (1997), in recognition of the fact that language learners enter the process of intercultural education from different points based on their diverse backgrounds, life experiences, and perspectives, and they move at different speeds, Deardorff (2006) offers a process-oriented, circular model of intercultural competence development in which the journey toward intercultural competence is never ending as the learner continues to learn, change, evolve and become transformed with time. The individual can enter the cycle at any point and move freely from internal outcomes - acquired culture-specific attitudes, knowledge and skills subsumed under an informed frame of reference (any shift in this frame leading to adaptability, flexibility, empathy, etc. would constitute an outcome), and external outcomes related to intercultural interactions (e.g. effective and appropriate communicative behavior in a context of intercultural contact) (Deardorff 2006: 254).

Publications on the practical perspectives of intercultural language education also offer a rich repertoire of learner activities aimed at developing the dichotomous unity of intercultural communicative competence. Depending on the targeted component of intercultural competence in focus, these activities can be grouped as follows (although distinctions are often blurred and savoirs of all sorts are tapped in one single activity):

- cognitive, or related to enhancing intercultural knowledge of social groups and their products and practices in the target language country and in one's own resulting in deeper understanding of both the "other" and the local culture (e.g. extracting culture-bound information when working with authentic materials, incl. literary and media texts, TV and audio broadcasts /podcasts, etc.; a discussion with a native speaker of the target language during which $\mathrm{s} /$ he talks about and explains his culture-specific beliefs, values and/or behaviors ${ }^{4}$; a theme project related to the gathering and presenting of some culture-specific information about local and foreign traditional celebrations and folk customs, or popular myths and legends, or national music and cuisine, etc.; producing a written or an online guide to learners' own country/hometown and local culture for foreign visitors, etc.);

- behavioral, or related to training the intercultural skills of interpreting and relating, of discovery and interaction, and critical cultural awareness (e.g. critical reading of an article or a literary text and reflection on the culture exponents present in the text; observation and critical evaluation of an event or cultural practice from the "other" culture, followed by its discussion, explanation/interpretation and possibly comparison with a similar event from the home culture; writing a travelogue of one's stay in the foreign country, reflecting on what one sees and how one feels in situations of intercultural communication; setting up video-conferences with peers from the other culture for them to share experiences and/or opinions about a document or an event; role-plays and simulations of critical incidents in cross-cultural communication leading to misunderstanding in which the learners are invited to take the role of mediators, identify and explaining the origins of conflict and intervening appropriately in order to facilitate communication, etc.);

- attitudinal, or related to developing the attitudes of openness and discovery which may require the relativisation of one's own values, beliefs and behaviors ${ }^{5}$, i.e. being ready to accept "that they are not the only possible and naturally correct ones, and to be able to see how they might look from an outsider's perspective who has a different set of values, beliefs and behaviors" (Byram, Gribkova \&

\footnotetext{
${ }^{4}$ However, as most native speakers of the target language would not be aware of the differences and similarities, learners must be ready to ask relevant questions, which capacity taps on their skills of discovery and interaction (cp. Byram, Nichols \& Stevens 2001: 6).

${ }^{5} \mathrm{~A}$ process which could be very challenging, because "however open towards, curious about and tolerant of other people's beliefs, values and behaviours learners are, their own beliefs, values and behaviours are deeply embedded and can create reaction and rejection" (Byram, Gribkova \& Starkey 2002:13).
} 
Starkey 2002:12) (e.g. reading and discussing guidebooks written by visitors to the learners' home country, commenting on their views; reading about a current, possibly controversial topic in the target language media and the ones in the home country, comparing the authors' viewpoints and public reaction to it; watching a relevant movie and reflecting on the exponents of cultural diversity; retelling a story from a different point of view, etc.).

Here follows just one example of how language teaching can acquire an intercultural dimension (not just cultural) and provoke learners into reflecting on and expressing their own cultural identity as they acquire the target language and learn about the culture of the target language speakers ${ }^{6}$.

\section{MYTH OI HISTORY}

A What do you know about the man in the picture? If you do not know who he was, talk about what you see in the picture and make a guess about who he was and when and where he lived. $\mathbb{B}$ Quickly read the text in $C$, ignoring the gaps and answer the questions below.

1 Who was Robin Hood?

2 What was he famous for?

C Read the text below and decide which answer $(a, b, c$ or d) best fits each gap.

Robin Hood is a legendary English folklore hero (1) _ was a highly skilled archer and swordsman. Some believe that he was a brave and witty outlaw who robbed the rich and (2)__ the wealth to the poor; others describe him (3)__ a nobleman who was loyal to King Richard I and helped him recover his throne.

The stories about Robin have appealed (4)__ common people throughout the ages because he stood up against social injustice and helped those (5)__ need. Furthermore, his life in Sherwood Forest with his fellow outlaws, the Merry Men, seemed like a great and noble adventure. His main opponent was the cruel and oppressive Sheriff of Nottingham. Robin Hood had a girlfriend, Maid Marian, and his companions included Little John, Alan-a-Dale, Much, Will Scarlett and a bit (6)___ a monk called Friar Tuck.

A collection of ballads about Robin Hood was published in England around 1489. (7)_ have been numerous variations and adaptations of the story (8)__ the following years, and the legend continues to be widely represented in literature and films.

1 a what b which cwho dwhom

2 a took b gave c brought d carried

3 a as b clike d such

4 a at b for cof d to

5 a of b in con d at

6 a on blate clater d after

7 a That b lt c Those d There

$\mathbf{8}$ a about bover cthrough d at

D Work with a partner and answer these questions.

- Can you think of some popular Bulgarian folklore heroes

(e.g. Krali Marko, Hitar Petar)? What do you know about them?

- Can you retell one of their stories?

E Read the text and complete it with these prepositions.

Speaking strategies: Retelling a story

- Set the scene (time/place) and introduce the main character(s). Make the introduction sound interesting.

- If necessary, give background information about the characters and/or what is happening.

- Describe the main events in logical order (from the problem to its solution) or follow the order in the original text.

- Use linking phrases (incl. time phrases) to sequence the events in the story.

- Use narrative tenses.

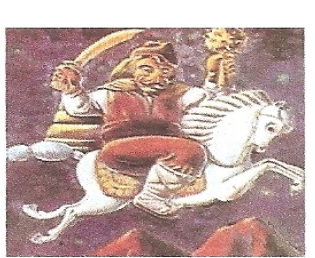

about for from into of on with

Krali Marko is a favourite Bulgarian folklore hero famous (1) great power and kind heart in all Balkan countries. He helped th and punished the evil. He fought (2)__ wild beasts and killed dragons. He was so strong that he could lift big rocks and throw them far away or cut them (3)___ two with his sword. People admired him.

There are many folk tales (4)__ him. Some even say that he was breastfed by a wood nymph and that baba Vida, whose castle you can still see in Vidin, was his girlfriend. According to another legend, one day, when Krali Marko was riding on the back (5) his horse, Sharkolia, he jumped (6) the Konyavska Mountain and landed (7)___ a rock near the village of Katrishte. Today, you can still see the place where the horse's foot sank into the stone.
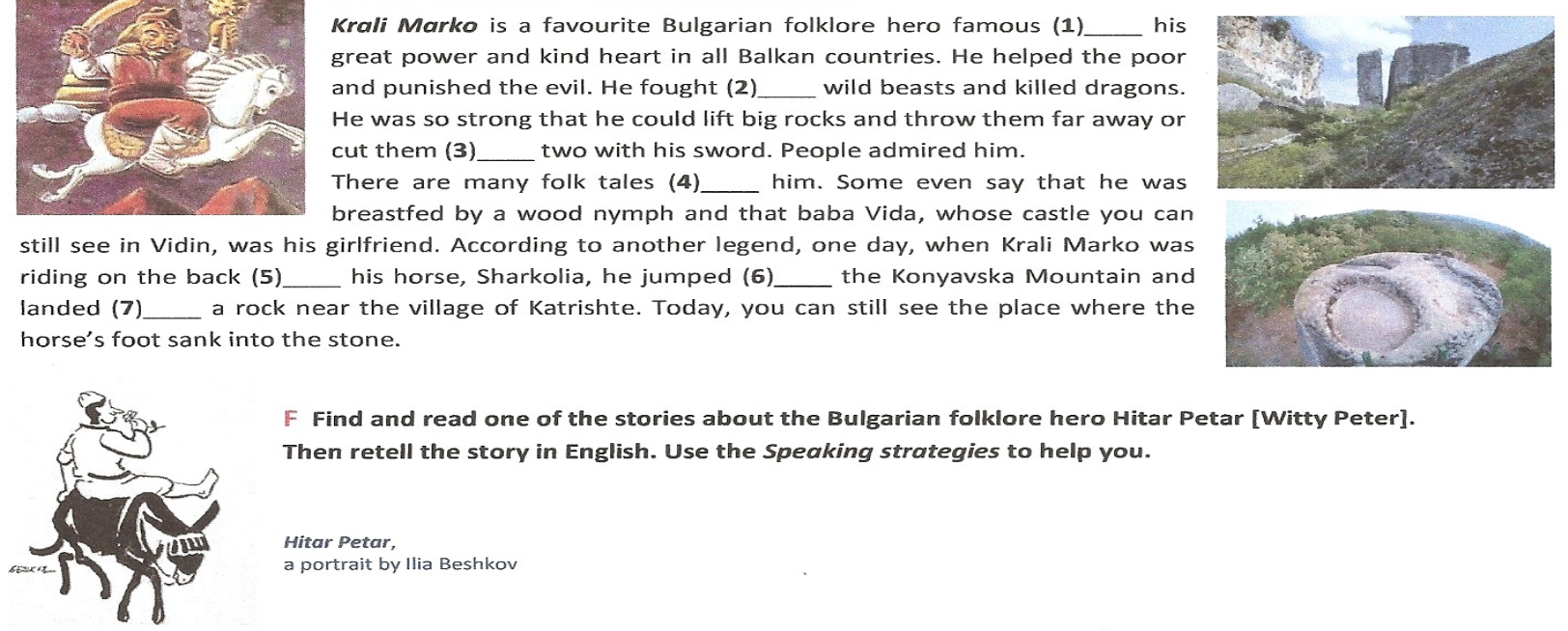

F Find and read one of the stories about the Bulgarian folklore hero Hitar Petar [Witty Peter]. Then retell the story in English. Use the Speaking strategies to help you. 
In the sample coursebook section above devoted to the expansion of the intercultural dimension of communicative competence, learners are initially invited to embark on a process of discovery about the iconic heroes, historical events and social values of the "other" culture (in this case related to the legend of Robin Hood). Then, in parallel to the analysis of otherness and the acquisition of knowledge about the target language culture, the learners are encouraged to explore the counterpart exponents of their home culture (Krali Marko and Hitar Petar) and improve their skills of presenting their own culture in the foreign tongue (i.e. their ability to "explain or discuss features of their own culture" - a B1 skill on the pluricultural competence chart from the CEFR, 2018: 159). Thus, through this set of language-focused activities, harnessing all the savoirs of intercultural competence from the three plains of reference (the cognitive, the attitudinal and the behavioural), learners not only enrich their knowledge about the target language culture, but also develop their interpretation and evaluation skills and adopt an attitude of appreciation for the beliefs and values of the people from the "other" culture as they gradually become aware of the similarities between their own culture and the foreign one.

\section{Conclusion}

It is a well-established fact that good educational theory informs and improves practice in the classroom, and practical experience from its application should serve as a corrector of theory, making it even more helpful for classroom practitioners in enhancing the quality of their teaching. The methodology of developing the intercultural communicative competence of language learners is a good example of this cognitive principle.

Communication skills and foreign language competence (or ever more often plurilingualism) have always been among the most essential life skills in any modern educational, professional or social context as every day we come in close contact with people of diverse cultural backgrounds speaking various languages. Training students for successful interaction in such multicultural settings predetermines the intercultural dimension of foreign language education (Sercu 2005) and highlights the close relationship between language and culture in the classroom. However, it should also be remembered that effective intercultural communicative competence goes beyond a good command of the target language and an insight into the culture related to it. Learners need to be aware of their own cultural identity and empowered with the necessary knowledge, skills and attitudes to function as efficient mediators in the process of intercultural communication. Thus this plurilinguistic and intercultural communicative competence can indeed become the main pillar of the European democratic citizenship, underpinned by an understanding of the values and principles on which the European peoples intend to base their development - democracy, social justice and respect for human rights (cp. Heater 1992). The educational role of language and the mission of language learning is probably best expressed in the following quote:

"There is nonetheless a fundamental values position which all language teaching should promote: a position which acknowledges respect for human dignity and equality of human rights as the democratic basis for social interaction" (Byram, Nichols \& Stevens 2001: 7).

\section{References}

Beacco, J.-C., Byram, M., Cavalli, M., Coste, D., Cuenat, M. E., Goullier, F. \& Panthier, J. (2016). Guide for the Development and Implementation of Curricula for Plurilingual and Intercultural Education. Strasbourg: Council of Europe Publishing.

Bennett, M. J. (1997). How Not to Be a Fluent Fool: Understanding the Cultural Dimension of Language, in: A. E. Fantini (Ed.) New Ways of Teaching Culture. Alexandria, VA: TESOL, 16-21.

Byram, M. (1997). Teaching and Assessing Intercultural Communicative Competence. Clevedon, UK: Multilingual Matters.

Byram, M., Nichols, A. \& Stevens, D. (Eds.) (2001). Developing Intercultural Competence in Practice. Clevedon, UK: Multilingual Matters. 
Byram, M., Gribkova, B. \& Starkey, H. (2002). Developing the Intercultural Dimension in Language Teaching: A Practical Introduction for Teachers. Strasbourg: Council of Europe.

Byram, M. \& Phipps, A. (Eds.) (2005). Foreign Language Teachers and Intercultural Competence. Clevedon: Multilingual Matters.

Byram, M. (2009). The intercultural speaker and pedagogy of foreign language education, in: D. K. Deardorff (Ed.), The Sage Handbook of Intercultural Competence. Los Angeles, CA: Sage, 321-332.

Canale, M. (1983). From communicative competence to communicative language pedagogy, in: J. C. Richards \& R. W. Schmidt (Eds.) Language and Communication. London: Longman, 2-27.

Canale, M. \& Swain, M. (1980). Theoretical bases of communicative approaches to second language teaching and testing. Applied Linguistics, 1 (1), 1-47.

Candelier, M., Camilleri-Grima, A., Castellotti, V., de Pietro, J.-F., Lörincz, I., Meissner, F. J., Schröder-Sura, A. \& Noguerol, A. (2007). Framework of Reference for Pluralistic Approaches to Languages and Cultures. Graz: European Centre for Modern Languages. http://carap.ecml.at/Portals/11/documents/C4pub2007E 20080302 FINAL.pdf. (31 May 2019).

Chomsky, N. (1965). Aspects of the Theory of Syntax. Cambridge MA: MIT Press.

Chomsky, N. (1980). Rules and Representations. Oxford: Blackwell.

Council of Europe (2001). Common European Framework of Reference: Learning, Teaching, Assessment. Cambridge: Cambridge University Press.

Council of Europe (2018). Common European Framework of Reference for Languages: Learning, Teaching, Assessment. Companion Volume with New Descriptors. https://rm.coe.int/cefr-companion-volume-with-newdescriptors-2018/1680787989. (1 August 2019).

Davcheva, L. \& Docheva, Y. (Eds.) (1998). Branching Out: A Cultural Studies Syllabus. Sofia: British Council and Tilia.

Deardorff, D. K. (2006). Identification and assessment of intercultural competence as a student outcome of internationalization. Journal Studies in International Education, 10 (3), 241-266.

Halliday, M. A. K. (1973). Explorations in the Functions of Language. London: Edward Arnold.

Halliday, M. A. K. (1978). Language as Social Semiotic. The Social Interpretation of Language and Meaning. London: Edward Arnold.

Healan, A., Gormley, K., Ludlow, K., Grozdanova, L. \& Dimitrova-Gyuzeleva, S. (2019). Close-up B1.1. Sofia: National Geographic Learning and Educational Centre.

Heater, D. (1992). Education for European Citizenship. Westminster Studies in Education, 15, pp. 53-67.

Høvik, K. Ø. (2019). English Subject Curriculum: Still Inspired by the Common European Framework of Reference for Languages? Paper presented at the 4th International Pedagogic and Linguistic ERL Conference "Educational Role of Language - From Theory to Practice, from Practice to Theory", University of Craiova, Romania, 17-18 June 2019.

Huber, J. (Ed.) (2012) Intercultural Competence for All: Preparation for Living in a Heterogeneous World. Strasbourg: Council of Europe Publishing.

Hymes, D. H. (1972). On communicative competence, in: J. B. Pride \& J. Holmes (Eds.) Sociolinguistics: Selected Readings. Harmondsworth, Middlesex: Penguin, 269-293.

Ivanov, A. (2018). Отродяване чрез принизяване и заличаване на българското. http://politkoment.blogspot.com/2018/05/. (8 September 2019).

Kramsch, C. (1993). Context and Culture in Language Teaching. Oxford: Oxford University Press.

Kramsch, C. (1998). Language and Culture. Oxford: Oxford University Press.

Lázár, I., Huber-Kriegler, M., Lussier, D., Matei, G. \& Peck, C. (Eds.) (2007). Developing and Assessing Intercultural Communicative Competence: A Guide for Language Teachers and Teacher Educators. Strasbourg: Council of Europe.

Murray, N. \& Thorne, T. (Eds.) (2004). Multicultural Perspectives on English Language and Literature, Tallinn and London: Tallinn Pedagogical University \& King's College London.

Sercu, L. (2005) Teaching Foreign Languages in an Intercultural World, in: M. Byram \& A. Phipps (Eds.), Foreign Language Teachers and Intercultural Competence. Clevedon: Multilingual Matters, 1-18.

Sun, Y. (2014) What Is Intercultural Communicative Competence? http://blog.tesol.org/what-is-interculturalcommunicative-competence/. (7 August 2019). 